\title{
Comparison of Enzyme-Immunoassay and Rapid Immunochromatography Test for Detecting Helicobacter pylori Stool Antigen
}

\author{
Dwi Prasetyo, ${ }^{1}$ Gerritsen H. J., ${ }^{2}$ Mertens P. ${ }^{3}$ Labrune V., ${ }^{3}$ Leclipteux T., ${ }^{3}$ Kuijper E. J. ${ }^{2}$ \\ ${ }^{1}$ Department of Child Health Faculty of Medicine Universitas Padjadjaran/Dr. Hasan Sadikin General \\ Hospital, Bandung, ${ }^{2}$ Department of Microbiology Leiden University Medical Center, The Netherland \\ ${ }^{3}$ Coris BioConcept, Gembloux, Belgium
}

\begin{abstract}
The rapid immunochromatography for Helicobacter pylori stool antigen (HpSA) test is a recently developed method for detection of Heicobacter pylori (H. pylori) infection. The objective of this study was to compare rapid HpSA test with a conventional enzyme-immunoassay (EIA) and to determine the prevalence of H. pylori infection in symptomatic (recurrent abdominal pain/RAP) Indonesian children. One hundred and two high school children aged 12-18 years old in Bandung with RAP from July to November 2008 were enrolled, excluding children who had additional symptoms, such as diarrhea or fever. First study was performed in 102 samples in laboratory of Leiden University Medical Center (LUMC), Helicobacter pylori infection was detected by a conventional EIA and rapid test. A second study was performed on a stored collection of 32 feces samples previously tested positive for H. pylori by EIA in laboratory of LUMC; these samples were retested by both assays. The results showed the sensitivity, specificity, positive predictive value, and negative predictive value of the rapid test were $100 \%, 98.2 \%$, accuracy $98.5 \%, 92.6 \%$ and $100 \%$, respectively, from 134 tested samples. The overall prevalence of H. pylori infection among Indonesian children was $3 \%$ by EIA at first testing. In conclusion, the prevalence of $\mathrm{H}$. pylori infection among symptomatic Indonesian children is very low and the new developed Pylori-Strip test shows good performance, very fast, and easy to use compared to EIA. [MKB. 2014;46(1):52-6]
\end{abstract}

Key words: Children, diagnostic, Helicobacter pylori, immunochromatography

\section{Perbandingan Pemeriksaan Enzyme-Immunoassay dan Rapid Immunchromatography untuk Mendeteksi Helicobacter pylori Stool Antigen}

\begin{abstract}
Abstrak
Pemeriksaan Helicobacter pylori stool antigen (HpSA) menggunakan rapid immunochromatography (rapid HpSA) merupakan metode yang saat ini sedang berkembang untuk mendeteksi infeksi $H$. pylori. Tujuan penelitian ini untuk membandingkan metode rapid HpSA dengan metode konvensional yaitu enzyme-immunoassay (EIA) dan menentukan prevalensi infeksi H. pylori pada anak dengan gejala sakit perut berulang (SPB) di Indonesia. Sebanyak 102 anak sekolah menengah usia 12-18 tahun di Bandung dengan keluhan SPB ikut dalam penelitian ini, dilaksanakan dari Juli-November 2008. Anak dengan gejala tambahan, seperti diare dan demam, dikeluarkan dari penelitian. Penelitian pertama dilakukan pada sampel feses 102 anak di laboratorium Leiden University Medical Center (LUMC), Helicobacter pylori terdeteksi baik dengan pemeriksaan EIA konvensional maupun rapid test. Penelitian kedua dilakukan pada 32 buah sampel feses simpanan di laboratorium LUMC yang sebelumnya menunjukkan hasil positif dengan pemeriksaan EIA, sampel ini juga diperiksa menggunakan kedua metode. Hasil penelitian menunjukkan sensitifitas, spesifisitas, akurasi, positive predictive value, dan negative predictive value, dengan hasil $100 \%, 98,2 \%, 98,5 \%, 92,6 \%$, dan $100 \%$ dari 134 sampel yang diuji. Prevalensi infeksi $H$. pylori pada anak Indonesia dengan keluhan SPB sekitar 3\% pada pemeriksaan pertama. Simpulan, prevalensi infeksi $H$. pylori pada anak SPB di Indonesia sangat sedikit dan pemeriksaan Pylori-strip (rapid test) merupakan pemeriksaan yang sangat baik dan cepat serta mudah digunakan dibandingkan dengan EIA. [MKB. 2014;46(1):52-6]
\end{abstract}

Kata kunci: Anak, diagnosis, Helicobacter pylori, immunochromatography

Correspondence: Dr. Dwi Prasetyo, dr., SpA(K), M.Kes, Gastroenterohepatology Division, Department of Child Health Faculty of Medicine Universitas Padjadjaran/Dr. Hasan Sadikin General Hospital Jalan Pasteur No.38 Bandung, mobile 081221623333, e-mail d pras2000@yahoo.com 


\section{Introduction}

Helicobacter pylori is one of the most common bacterial pathogens in human. Helicobacter pylori infection is currently recognized as a worldwide problem. It is well known that the childhood is an important period for $H$. pylori infection acquisition, especially in developing countries where the influence of socioeconomic factors on the prevalence of $H$. pylori infection has been shown. ${ }^{1-5}$

Association of symptoms with $H$. pylori infection in children presenting with nonulcer dyspepsia is controversial with one important controversy relates to the presence of recurrent abdominal pain (RAP) in children. A study conducted in Iran shows that among 430 children and adolescent, $47 \%$ infected by $H$. pylori, $82 \%$ experienced RAP. ${ }^{5}$ The classic symptoms of peptic gastroduodenal disease are dyspepsia, vomiting, hemetemesis, melena, and epigastric abdominal pain. ${ }^{6}$

There are several methods used for diagnosing H. pylori infection including invasive procedures using mucosa biopsies taken during endoscopy (mainly culture, histology and the rapid urease test) and noninvasive procedures (mainly $13 \mathrm{C}$ or $14 \mathrm{C}$ urea breath test (UBT), serological test and HpSA test. ${ }^{7}$ The gold-standard diagnostic test remains endoscopy with biopsy analyses. However, invasive tests are not always suitable for the pediatric population; hence, there is an increased interest in noninvasive tests for children. ${ }^{8-11}$ Several non-invasive methods are available for the diagnosis of $H$. pylori infection, but so far tests for detection of $H$. pylori antigen in stools have been the only non-invasive diagnostic tools which do not show age dependence for the diagnostic accuracy. ${ }^{12}$

Helicobacter pylori stool antigen test is a useful non-invasive method for $H$. pylori infection diagnosis and monitoring. The basic technique in a conventional HpSA test is the enzyme linked immunosorbent assay (ELISA) method (HpSA ELISA) and HpSA ELISA has been applied in both adults and children with high diagnostic accuracy. 5,9,11-14

A rapid 5-min immunoassay for $\mathrm{HpSA}$ or rapid $H p S A$ test using a monoclonal anti- $H$. pylori antibody is recently developed based on a lateral flow immunochromatography technique. It is a convenient office-based method for detection of $H$. pylori antigen in stool specimens. However, only a few validation studies have compared the diagnostic accuracy of the rapid HpSA test with that of the HpSA ELISA in children. ${ }^{14}$ The aims of this study were to compare a new developed rapid HpSA test with a conventional enzyme- immunoassay (EIA) and to determine the prevalence of $H$. pylori infection in symptomatic Indonesian children.

\section{Methods}

A total of 102 high school Indonesian children in Bandung with RAP from July to November 2008 were enrolled. The age range of the children was 12-18 years. The children who had additional symptoms, such as those with diarrhea or fever, were excluded from this study. Helicobacter pylori infection in first study was detected using a conventional EIA (Amplified IDEIA Hp StAR, Oxoid, United Kingdom) and using a rapid test (Pylori-Strip, Coris BioConcept, Gembloux Belgium) in the laboratory of Leiden University Medical Center (LUMC). A second study was performed on a stored collection of 32 faeces in laboratory of LUMC, previously tested positive for $H$. pylori by EIA; these samples were retested by both assays. Stool specimens were collected in empty containers from all patients for the HpSA tests performed using both a conventional EIA (Amplified IDEIA Hp StAR, Oxoid, United Kingdom) and by a rapid test (Pylori-Strip, Coris BioConcept, Gembloux Belgium). Stool samples were stored at $-20{ }^{\circ} \mathrm{C}$ upon receipt before testing. The HpSA EIA was performed according to the manufacturer's procedure. The methods used were as follows. After emulsifying a portion of stool into $200 \mu \mathrm{L}$ sample diluents in a test tube, $50 \mu \mathrm{L}$ of the diluted stools and controls were transferred into microwells. One drop of enzyme conjugate was added to each well and the well was sealed. The mixture was then incubated at room temperature for 1 hour. After washing five times with the wash buffer, two drops of the substrate solution were added to each well and incubated at room temperature for 10 minutes. One drop of stop solution was added to each well, and the results were spectrophotometrically read at dual wavelengths of $450 \mathrm{~nm}$. According to manufacturer's instructions, an absorbance at $450 \mathrm{~nm}$ of $<0.100$ was defined as negative and of $>0.100$ was defined as positive, respectively. The kit for the rapid HpSA test contained a test card and sample diluents, which had been stored at $2-8{ }^{\circ} \mathrm{C}$ before testing. Using the applicator stick of the diluent vials, a small portion (5-6 mm diameter) of the stool specimen as transferred into the sample diluents and vortex mixed for 15 seconds. By holding the vial and breaking the tip off, 4 drops of stool mixture were dispensed into the round window indicated by an arrow at the lower end of the test card. The results of the rapid HpSA test were interpreted as positive 
Dwi P.: Comparison of Enzyme-Immunoassay and Rapid Immunochromatography Test for Detecting Helicobacter pylori

Table 1 First Test on 102 Samples

\begin{tabular}{llllll}
\hline & \multicolumn{2}{c}{ EIA } & \multicolumn{2}{c}{ Pylori-Strip } \\
\cline { 2 - 6 } & First Test & Second Test & First Test & Second Test & Status \\
\hline 96 samples & Negative & Negative & Negative & Negative & TN \\
3 samples & Positive (low) & Negative & Negative & Negative & TN \\
2 samples & Negative & Negative & Positive & Negative & TN \\
1 samples & Negative & Negative & Positive & Positive & FP \\
\hline
\end{tabular}

Note: Status (EIA as the reference method): TN: true negative; FP: false positive

when a distinguishable pink-red band appeared in addition to a blue control line after 5 minutes. Results were considered negative when only a blue control line appeared after 5 minutes. Data were analyzed with diagnostic test using sensitivity, specificity, accuracy, positive predictive value and negative predictive value.

\section{Results}

First test were performed in 102 samples of high school children with RAP. Each samples were tested using both the conventional EIA and rapid HpSA. From 102 samples that were tested, 96 samples were negative in the first and second tests in both of EIA and pylori strip, 3 low positive samples in the first EIA test were negative in the second EIA test (after 30 minutes) and both pylori strip tests, 2 negative samples in the first and second EIA test were positive in the first pylori test but negative in the second test. One negative sample in both of the EIA test was positive in both of the pylori strip test. The overall prevalence of H. pylori infection among Indonesian children was $3 \%$ by EIA at first testing.

A second study was performed on 32 faeces samples from stored collection, previously tested positive for $H$. pylori by EIA. They were retested by both assays.

From 32 faeces samples from stored collection, previously tested positive for $H$. pylori by EIA, were retested by both assays, 24 samples were positive in EIA test and both tests of pylori strip. One positive sample in EIA test was negative in the first test, but positive in the second test (after 30 minutes) of pylori strip. Six negative samples in EIA test were negative in both tests of pylori strip. One negative sample in EIA test was positive in both tests of pylori strip.

The sensitivity, specificity, accuracy, positive predictive value, and negative predictive value of the rapid test were $100 \%, 98.2 \%, 98.5 \%, 92.6 \%$ and $100 \%$, respectively when calculated on the 134 tested samples and including the results of the repeated test.

\section{Discussion}

Helicobacter pylori infection can be diagnosed by using invasive techniques requiring endoscopy and biopsy or by using noninvasive techniques. The gold standard is generally endoscopic biopsybased methods. Although $H$. pylori infection is generally diagnosed using endoscopic biopsybased methods, the application these methods in children is limited because upper gastrointestinal endoscopy is an invasive and expensive procedure. Ideally, a diagnostic test for $H$. pylori infection in children should be non-invasive, highly sensitive and specific, inexpensive and easy to perform. ${ }^{15}$

Table 2 Second Test on 32 Stored Samples Which were Previously EIA Positive Tested

\begin{tabular}{llllll}
\hline & & \multicolumn{3}{c}{ Pylori-Strip } \\
\cline { 3 - 6 } & & EIA & First Test & Second Test & Status \\
\hline 24 samples & Positive & Positive & Positive & TP & TN \\
1 sample & Positive & Negative $* 1$ & Positive & FN & TN \\
6 samples & Negative & Negative & Negative & TN & TN \\
1 sample & Negative & Positive & Positive & FP*2 & FP \\
\hline
\end{tabular}

Note: Status (EIA as the reference method):TP: true positive; TN: true negative; FP: false positive; FN: false-negative

$* 1$ : positive after 30 minutes $* 2$ : positive in pylori strip 
Table 3 Sensitivity, Specificity, Accuracy, Positive Predictive Value, and Negative Predictive Value of Rapid Test

\begin{tabular}{cccc}
\hline \multirow{2}{*}{ Pylori-strip } & \multicolumn{3}{c}{ EIA } \\
\cline { 2 - 4 } & + & - & Total \\
\hline+ & 25 & 2 & 27 \\
- & 0 & 107 & 107 \\
& 25 & 109 & 134 \\
\hline
\end{tabular}

Thus several noninvasive method have been widely used as the preferred diagnostic methods in pediatric populations for detection of $H$. pylori infection. Among the noninvasive methods, the HpSA test is regarded as an important diagnostic test in children because it is more accurate than serology and the kit required for it is more readily available than that for the UBT.

Helicobacter pylori stool antigen test is a reliable noninvasive method for detecting $H$. pylori antigens in stool specimens. ${ }^{14}$ The advantages of HpSA test include that it is noninvasive, specimen can be collected, transported, and preserved easily, test results are not affected by medication being taken by patient, test results are clear, no invasive procedure such as endoscopy is required, and it is cost-effective.

The conventional HpSA test using ELISA was developed in 1998 and has been applied in both adults and children. The Helicobacter pylori stool antigen ELISA has been shown to be accurate in diagnosing $H$. pylori infection in adults. Furthermore, several studies performed in children also showed high diagnostic accuracy before and after eradication therapy. ${ }^{14,16}$

However, the HpSA ELISA has several certain disadvantages. This assay takes more than 2 hours to perform and also requires laboratory equipment and a skilled technician. Thus, the HpSA ELISA appears inappropriate as an office-based diagnostic method in primary practice, because simple and convenient noninvasive methods are preferred as diagnostic tools. ${ }^{14}$

Recently, the rapid HpSA method using a monoclonal anti-H. pylori antibody was developed on the basis of lateral flow immunochromatography. It is highly suitable for the detection of $H$. pylori in practice, because it is a rapid one-step single test. ${ }^{17,18}$ There have been several validation studies on the rapid HpSA test in children. ${ }^{12,19}$ However, only a few published studies have compared the diagnostic accuracy of the rapid HpSA test with that of the HpSA ELISA in children. ${ }^{12,19}$ In this study, we attempted to compare a new developed rapid HpSA test with a conventional EIA and to determine the prevalence of $H$. pylori infection in symptomatic Indonesian children.

Previous studies on HpSA ELISA in pediatric populations show a sensitivity and specificity that range from $89 \%$ to $97 \%$ and from $95 \%$ to $99 \%$, respectively. ${ }^{14,19}$ The sensitivity and specificity of the rapid HpSA test reported in previous studies in pediatric population were $86-91 \%$ and 88 $98 \%$, respectively. ${ }^{14,15}$ Our study revealed high diagnostic accuracy with a sensitivity of $100 \%$ and specificity of $98.2 \%$. From these results, both the HpSA ELISA and the rapid HpSA test were found to be reliable noninvasive methods for diagnosing $H$. pylori infection in children.

In our study, the overall prevalence of $\mathrm{H}$. pylori infection in symptomatic Indonesian children was $3 \%$ by EIA at first testing. This is possibly due to the strain-specific differences in antibody responses in different populations. In addition, it has been suggested that EIA kits validated in one region may yield variable diagnostic performance results in different regions.

It is concluded that the diagnostic accuracy of the two HpSA tests was high; therefore, both HpSA tests are reliable noninvasive methods for diagnosing $\mathrm{H}$. pylori infection in children. In particular, that new developed Pylori-Strip test has excellent performance and is very rapid and easy to use as compared to EIA. The prevalence of $H$. pylori infection in symptomatic Indonesian children is very low.

\section{References}

1. Rosenberg JJ. Helicobacter pylori. Pediatr Rev. 2010;31(2):85-6.

2. Tonkic A, Tonkic M, Lehours P, Megraud F. Epidemiology and diagnosis of Helicobacter pylori infection. Helicobacter. 2012;17 Suppl 1:1-8.

3. Erzin Y, Altun S, Dobrucali A, Aslan M, Erdamar S, Dirican A, et al. Evaluation of two enzyme immunoassays for detecting Helicobacter pylori in stool specimens of dyspeptic patients after eradication therapy. J Med Microbiol. 2005;54(Pt 9):863-6.

4. Das JC, Paul N. Epidemiology and pathophysiology of Helicobacter pylori infection in children. Indian J Pediatr. 2007;74(3):287-90.

5. Falsafi T, Valizadeh N, Sepehr S, Najafi M. Application of a stool antigen test to evaluate the incidence of Helicobacter pylori infection in children and adolescents from Tehran, Iran. Clin Diagn Lab Immunol. 2005;12(9):10947.

6. Jones NL, Walters TD. Helicobacter pylory in childhood. In: Wyllie R, Hyams JS, editor. 
Pediatric gastrointestinal and liver disease. $3^{\text {rd }}$ edition. Philadephia: WB Saunders; 2006. p. 409-37.

7. Li YH, Guo H, Zhang PB, Zhao XY, Da SP. Clinical value of Helicobacter pylori stool antigen test, ImmunoCard STAT HpSA, for detecting $\mathrm{H}$ pylori infection. World $\mathrm{J}$ Gastroenterol. 2004;10(6):913-4.

8. Sabbi T, De Angelis P, Colistro F, Dall'Oglio L, di Abriola GF, Castro M. Efficacy of noninvasive tests in the diagnosis of Helicobacter pylori infection in pediatric patients. Arch Pediatr Adolesc Med. 2005; 159(3):238-41.

9. Ni YH, Lin JT, Huang SF, Yang JC, Chang $\mathrm{MH}$. Accurate diagnosis of Helicobacter pylori infection by stool antigen test and 6 other currently available tests in children. J Pediatr. 2000;136(6):823-7.

10. Ukarapol N, Lertprasertsuk N, Wongsawasdi L. Recurrent abdominal pain in children: the utility of upper endoscopy and histopathology. Singapore Med J. 2004;45(3):121-4.

11. Gulcan EM, Varol A, Kutlu T, Cullu F, Erkan T, Adal E, et al. Helicobacter pylori stool antigen test. Indian J Pediatr. 2005; 72(8):675-8.

12. Schwarzer A, Lottspeich C, Russmann H, Ossiander G, Koletzko S. Evaluation of a novel rapid one-step monoclonal chromatographic immunoassay for detection of Helicobacter pylori in stool from children. Eur J Clin Microbiol Infect Dis. 2007;26(7):475-80.

13. Cardinali LCC, Rocha GA, Rocha AMC, Moura SB, Soares TF, Esteves AM, et al. Evaluation of $[13 \mathrm{C}]$ urea breath test and Helicobacter pylori stool antigen test for diagnosis of $\mathrm{H}$. pylori infection in children from a developing country. J Clin Microbiol. 2003;41(7):3334-5.

14. Yang HR, Seo JK. Helicobacter pylori stool antigen (HpSA) tests in children before and after eradication therapy: comparison of rapid immunochromatographic assay and HpSA ELISA. Dig Dis Sci. 2008;53(8):2053-8.

15. Leal YA, Cedillo-Rivera R, Simon JA, Velazquez JR, Flores LL, Torres J. Utility of stool sample-based tests for the diagnosis of Helicobacter pylori infection in children. $J$ Pediatr Gastroenterol Nutr. 2011;52(6):71828.

16. Gisbert JP, Pajares JM. Stool antigen test for the diagnosis of Helicobacter pylori infection: a systematic review. Helicobacter. 2004;9(4):347-68.

17. Wu IC, Ke HL, Lo YC, Yang YC, Chuang $\mathrm{CH}$, Yu FJ, et al. Evaluation of a newly developed office-based stool test for detecting Helicobacter pylori: an extensive pilot study. Hepato-gastroenterology. 2003; 50(54):1761-5.

18. Trevisani L, Sartori S, Rossi MR, Ruina M, Matarese V, Gullini S, et al. Evaluation of a new rapid immunoassay for the detection of Helicobacter pylori in faeces: a prospective pilot study. Aliment Pharmacol Ther. 2005; 21(4):485-9.

19. Kato S, Ozawa K, Okuda M, Nakayama Y, Yoshimura N, Konno M, et al. Multicenter comparison of rapid lateral flow stool antigen immunoassay and stool antigen enzyme immunoassay for the diagnosis of Helicobacter pylori infection in children. Helicobacter. 2004;9(6):669-73. 